III International Theoretical and Practical Conference "The Crossroads of the North and the East (Methodologies and Practices of Regional Development)"

DOI: 10.32743/nesu.cross.2020.91-96

\title{
Image of the North-East of Russia in the Representation of Karelian Students Olga V. KLYPA
}

\author{
Dr. habil. (Psychology), Associate Professor \\ Professor of the Department of Pedagogy and Child Psychology \\ Institute of Pedagogy and Psychology \\ Petrozavodsk State University \\ 33 Lenin Avenue, Petrozavodsk, 185910, Russia \\ ovk61@mail.ru
}

\begin{abstract}
The article justifies the relevance of the research by the fact that the process of transition of Russian society to a fundamentally new basis of economic, socio-political and socio-cultural development cannot be successful without the formation of the image of Russia among young people. The article analyzes the differences between the concepts of "image" and "reputation" of the region, and points out the importance of forming one's own portrayal of the far Eastern region of the country. The purpose of the research is to study the image of the North-East region of Russia formed in the minds of students of the Republic of Karelia. The article considers the results of a pilot empirical study conducted by the method of questionnaires and using the "mental map" method and "association test" with a total sample size of 43 people aged 17 to 24 years. The results of the research allow us to speak about the heterogeneity of the image of the North-East of the Russian Federation in the representation of young people.
\end{abstract}

Keywords: North-East of Russia; image and reputation of the region.

\section{Introduction}

The question of Russia's image in the world community is now more relevant than ever. Quite a large number of works are devoted to the study of the image of Russia abroad. Recently, there have been a significant number of studies dedicated to the study of the image of the region in our country, but there are very few studies aimed at studying the image of the North-East of Russia.

The formation of the image of the Russian Federation is impossible without the formation of images of its regions that differ from each other in a number of parameters of natural-geographical, resource-economic, ethnic, and cultural character. It should be assumed that each region strives to use its own image (reputation) as a mechanism for its own development in the future.

It is important to emphasize that the concept of "image" and "reputation" are not identical, although they are closely related to each other and have their own characteristics. "Reputation" is a representation that is constructed purposefully and consciously, while "image" is formed spontaneously, it can be diagnosed and described (Gurov, Korzuhina, 2016). The image of a territory is an arbitrary idea that people have formed about it. Reputation - a stereotyped image of the territory in the public consciousness, formed under the influence of information and communication technologies. The reputation of a territory is linked to the public's assessment of the activities of its residents.

The image is the basis for the formation of the reputation, which, in turn, is a tool for the competitiveness of the region. The image of the region may be internal and external: the internal image is associated with the assessment of the region by its inhabitants, external image - the 
assessment of the region by people living outside the area. The internal image of a region allows you to evaluate its reputation by such parameters as comfort of living, quality of life, opportunities for self-realization in territorial space, etc., at the same time, it is extremely important that the internal image of the region among the youth living in it is positive, since the future of the region depends on a positive assessment of the youth. The external image of the region is associated with a set of features and characteristics that are, on the emotional and psychological level of the general public, associated with a specific geographical area that has special socio-cultural characteristics. The positive external image of the region is a factor of the inflow of highly qualified specialists, investment, social and cultural development.

One of the most important national tasks is the development of the Far East. The Minister of the Russian Federation for the development of the Far East and the Arctic, Kozlov, points to the need to create such comfortable conditions for the life of far Easterners that would help to stop the outflow of people and ensure their inflow (FANU "Vostokgosplan", 2019). This largely depends on what image of the Far East was formed in the minds of people, and especially young people living outside of this region.

The purpose of this research is to study the image of the North-East of Russia in the representation of student youth in Karelia, the North-Western territory of Russia.

The study participants were 1st - 4th year students of the Institute of Pedagogy and Psychology of Petrozavodsk State University, specializing "Pedagogical education", profile "Preschool education" (bachelor's degree). A total of 43 people aged 17-24 years took part in the study.

\section{Methods}

A pilot empirical study of the image of the North-East of Russia was conducted on the basis of the "mental map" technique, which allowed to obtain a generalized image of the region in the mind (imagination) of the respondent, an association test, and a questionnaire.

Mental map (mindmapping, author Tony Buzan (Buzan, Griffiths, 2013) - an effective and convenient technique for visualizing thinking and alternative recording - was used to analyze and clarify information about the image of the North-East of Russia in the representation of Karelian students. The mental map of the region allowed us to "extract" the most common visual images associated with the idea of the North-East of Russia from the respondents.

The research procedure was as follows: first, students were asked to outline the map of the Russian Federation with a pencil, highlight and shade the North-Eastern region of Russia with the designation of areas and important objects (cities) from their point of view; then write wordsassociations that arise when perceiving such words and phrases as "North-East of Russia", "Magadan", "Kolyma", and also determine which one color these words are associated with; answer questions: "Have you visited cities in the North-East of Russia?» and "Would you like to visit Magadan? Why?"

\section{Results}

The data obtained in the course of the study demonstrated the presence of two levels of interpretation of the image of the North-East of Russia in the minds of respondents: cartographic and pragmatic (understanding and interpretation of language signs).

Analysis of mental maps shows that $33 \%$ of respondents failed to complete the task: they did not correctly display the territory of the North-East of Russia (Magadan region, Kamchatka region, Chukotka autonomous district), highlighting instead the territory of the Northern part of Siberia; they could not mark the main cities of the North-Eastern territory of Russia (Magadan, Anadyr, Pevek, Petropavlovsk-Kamchatsky). 
When offering students an association test, we asked them to write down what first came to mind when they perceived the following words and phrases: "North-East of Russia", "Magadan", "Kolyma". Table 1 shows the word associations in the perception of the above words of the phrase.

Table 1. Word associations in the perception of the above words of the phrase

\begin{tabular}{|c|c|}
\hline Words of the phrase & $\begin{array}{l}\text { Association words, that occur during perception of the words and phrases } \\
\text { (the number of responses is shown in parentheses) }\end{array}$ \\
\hline \multirow[t]{3}{*}{ North-East of Russia } & $\begin{array}{l}\text { "cold" (43), "snow" (6), "wind" (6), "narrow eyes" (1), "few cities" (34), } \\
\text { "many rivers" (2), "2 hours difference with Moscow" (1), "bad roads" (3), } \\
\text { "port" (2), "forest" (3), "hunting" (2), "beautiful nature" (7), "ashberry" (1), } \\
\text { "good/kind people" (4), "small population" (1), "bad and beautiful at the same } \\
\text { time" (1), "remoteness" (9), "uncertainty" (1), "distance" (1), "big cities" (2), } \\
\text { "high income" (14), "volcanoes" (3), "deers" (1), "sea" (7), "Baikal" (1), } \\
\text { "Pacific ocean" (4), "Arctic ocean" (1), "Siberia" (11), "Yakutia" (4), } \\
\text { "Kolyma" (1), "Chukotka" (2). }\end{array}$ \\
\hline & $\begin{array}{l}\text { Cities in the North-East of Russia: "Chelyabinsk" (3), "Tomsk" (1), } \\
\text { "Nizhnevartovsk" (1), "Yekaterinburg" (5), "Ufa" (1), "Irkutsk" (1), } \\
\text { "Murmansk" (1), "Yakutiya" (8), "Yakutsk" (4), "Sahalin" (3), "Ohotsk" (1), } \\
\text { "Vladivostok" (1), "Magadan" (2), "Petropavlovsk-Kamchatsky" (1), "I don't } \\
\text { know" (14). }\end{array}$ \\
\hline & $\begin{array}{l}\text { Color: "grey-green" (1), "grey" (32), "violet" (2), "blue" (1), "white" (5), } \\
\text { "brown" (2). }\end{array}$ \\
\hline \multirow[t]{2}{*}{ Magadan } & $\begin{array}{l}\text { "too cold" (40), "warm" (1), "too far" (18), "mountains" (15), "beautiful } \\
\text { nature" (3), "the population is the same as in Petrozavodsk" (8), "population - } \\
300 \text { people" (1), "the song "I'm driving to Magadan"” (37), "difficult } \\
\text { situation" (2), "firewood" (1), "prison" (4), "GULAG" (2), "Stalin's } \\
\text { repressions" (4), "there are no associations" (33). }\end{array}$ \\
\hline & Color: "white" (26), "grey" (12), “yellow" (2), “red" (1), “orange” (2). \\
\hline \multirow{2}{*}{ Kolyma } & $\begin{array}{l}\text { "something Russian, ancient, traditional" (1), "city" (4), "Kolyma river" (1), } \\
\text { "place of detention" (1), "there are no associations" (38). }\end{array}$ \\
\hline & $\begin{array}{l}\text { Color: "grey" (26), "white" (6), "black" (3), "snowy" (1), "violet" (1), } \\
\text { "cold" (3), "frosty white" (1), "I don’t know" (2). }\end{array}$ \\
\hline
\end{tabular}

The largest number of word associations related to the phrase "North-East of Russia", the smallest "Kolyma". It should be recognized that students do not know the geography of Russia (the NorthEast of Russia is associated with the North of Siberia). The association with color allows us to conclude about the attitude of respondents to the images of "North-East of Russia", "Magadan", "Kolyma": as a rule, these images are associated with the concept of "gray" (54\%), and "white" (29), several respondents associate these images with the color concept "cold" and even "black". The image of "Magadan" in individual respondents (4\%) is associated with warm colors ("red", "yellow", "orange"), which is directly related to the famous slang "Sunny Magadan".

In the course of analyzing the responses to the questionnaire, it turned out that $100 \%$ of the respondents answered "no" to the question "Have you visited the cities of the North-East of Russia?". To the question "Would you like to visit Magadan? Why?": 72\% answered " Yes " ("to see Russia"; "to see the far Eastern nature"), 22\% - "no", ("not interested"; "no money"; "far from home and cold"); 6\% - "I don't know".

It is obvious that the image of the region in the subject's mind is influenced by various factors: the media, the school curriculum in geography, history, literature, and personal experience. The results of the study showed inadequate knowledge level of students of North-East Russia, Magadan - the 
capital of the Kolyma region (Magadan oblast), the city of Anadyr - the capital of Chukotka (Chukotka autonomous district).

Along with that the analysis of materials allows us to conclude that the North-East of Russia is more defined by students as a remote cold, snowy, windy region with a small number of cities and high wages, and Magadan as a city with a population of 300 people, a peculiar nature, a dark past and a difficult situation in the present, located very far from Central Russia. A large majority of students want to visit Magadan city.

Represented in the empirical research data can be the basis for discussion and stimulation of work of administration of the Magadan region and leadership of the Northeastern State University in the direction of shaping the public image of the region.

It can be assumed that we would get a similar picture when studying the image of the Republic of Karelia (North-Western region of Russia) in the representation of the student youth of Magadan. It would be interesting to analyze the results of research in this direction and make a comparative analysis.

\section{Discussion}

Modern research shows the interest of scientists in the problem of forming an effective image of the territory. The works of foreign researchers - Anholt (1998, 2007), Fetscherin (2008), Govers (2018), De Wit, Hunter, Howard, and Egron-Polak (2015), and others - actively discuss the development of the image, character, reputation of the territory, the mechanisms of their formation. The concept of "image" in the works of these scientists is a complex socio - psychological education by its nature, it is an artificial image formed in the public or individual consciousness through mass communication, combining both real information about the territory and fictional. The works emphasize the importance of marketing activities (branding) first of all aimed at creating a positive image: positioning the territory as a cultural, historical, tourist center, creating a slogan, visual symbol, holding a major event, etc.

The works of Russian authors Gurov and Korzuhina (2016), Terskiy and Malenova (2015), Chepkasov (2016) and others also consider both general problems of developing the image of the region, and issues of forming the image of specific subjects of the Russian Federation and Russian cities. The authors note that creating an effective image of the territory is a complex task associated with the creation of corrective programs aimed at approaching the ideal image of the territory. The ideal image is associated with the idea of what the region (territory) should be. Researchers discuss the main factors that shape the territory's image: natural potential, national and cultural heritage, unregulated geopolitical factors, historical facts, etc. Various communication channels through which information about the territory is brought to the attention of not only internal, but also external groups of the public have a huge impact on creating the image of the territory: the internet, television, special events that allow you to convey the cultural specifics of the region, its features and achievements, individuals getting a personal impression by visiting the territory.

It is obvious that creating and developing the image of the territory is an important strategic multifaceted area of work for the region's leaders. In Russia, there are still few examples of regional and municipal authorities seriously dealing with the problem of promoting information and maintaining a favorable image of the territory. First of all, this concerns the external image of the region, which requires interaction between various subjects of the Russian Federation and the extensive use of information technologies. As a rule, important and useful information does not appear in the central news that forms public opinion. An example is a study that revealed that the students of the NorthWest region of the country know very little about the North-East of Russia, in particular, about the Kolyma region and the city of Magadan. The North-East of Russia is represented by the youth of Karelia as a remote, borderline, harsh region, not particularly promising in socio-economic terms. 
In their view, the Kolyma region has an image that was formed in the Soviet period - the GULAG region, which negatively affects the formation of the image of this territory. It should be noted that the students who took part in the survey know almost nothing about the GULAG in the Karelian Republic.

The need to create own image of the Kolyma region (Magadan region), the city of Magadan, its recognition, a positive image is obvious, because this could help attract attention to the region, make it possible to more effectively defend its interests, increase the investment fund, and ultimately contribute to the formation of the image of Russia. It is necessary to strive to make sure that as much as possible is known about the region, and it is very important that information about it is positive. In this regard, there is a clear need to discuss the prospects for improving the image of the Kolyma region (Magadan region) and the city of Magadan.

\section{Conclusion}

The North-East of Russia plays a key role in Russia's geopolitical and economic interests. First of all, this is due to the huge reserves of natural resources, geographical location, economic potential, etc. At the same time, we should also note a number of problems, which can include an underpopulated region, a high degree of migration, and a low birth rate. The North-East of Russia objectively needs migration growth at the expense of the country's youth.

In the Soviet Union (in the 1960s-80s), this problem was tried to be solved by distributing graduates of universities and colleges, komsomol calls, etc. Migration flows not only developed already actively functioning cities and towns, but also contributed to the establishment of new settlements. Unfortunately, over the past decades (since the 90s of the XX century), there has been a reverse movement of the vector of migration flows from the North-Eastern region to the Western, Central and Southern regions of the Russian Federation. There are a number of reasons for migration of the population of the North-East, among which, in addition to the geographical factor (severe, sometimes extreme, natural and climatic conditions), both economic and psychological factors are significant.

Currently, the Federation Council Committee on federal structure, regional policy, local selfgovernment and Northern affairs actively solves various acute specific socio-economic problems of the North-Eastern region of Russia related to regional unique characteristics. The Committee's activities are aimed at improving the quality of life of northerners.

In particular, the national development program of the Far East until 2025 assumes the implementation of multidirectional national projects, among which projects in the field of education and science considered significant (FANU "Vostokgosplan", 2019). In this regard, we should contemplate the possibility of scientific inter-university cooperation between universities in the Northern regions of our country, which will contribute to the formation of the image of the regions. It is important at the level of the Ministry of science and higher education of the Russian Federation to consider the strategic question of partnership between universities within the country, to increase teaching and student mobility aimed at joint research projects and events, as was the case in the Soviet Union: students had the opportunity to travel to conferences, practice in other regions of the country (from the Central regions to the Far East, and from the Far East to the Central regions) at the expense of public funds. Academic mobility of teachers and students significantly influenced the image of the university, region, and city. Many students after graduation pursued employment in different regions of the country. Unfortunately, at present, priority is given to international cooperation of higher education institutions at the expense of expanding cooperation of Russian universities.

Inter-university (inter-regional) cooperation should be aimed at developing innovative processes in higher education institutions, a more flexible system of training specialists, improving the quality of 
III International Theoretical and Practical Conference "The Crossroads of the North and the East (Methodologies and Practices of Regional Development)"

joint research, etc.

\section{References}

Anholt, S. (1998). Nation Brand of the Twenty-First Century. The Journal of Brand Management, 5(6), 395-404.

Anholt, S. (2007). Competitive Identity: The New Brand Management for Nations, Cities and Regions. Basingstoke: Palgrave Macmillan.

Buzan, T., \& Griffiths, C. (2013). Modern Mind Mapping for Smarter Thinking. Proactive Press.

Chepkasov, A. V. (2016). Image - reputation - stereotype of the region (to the explanation of definitions). Bulletin of NSU Series: History, Philology, 15(6), 83-92. (in Russian)

De Wit, H., Hunter, F., Howard, L., \& Egron-Polak, E. (2015). Internationalisation of higher education. Brussels: European Union. https://doi.org/10.2861/6854

FANU "Vostokgosplan". (2019). Proposals to the draft of the National program for the development of the Far East. Retrieved from https://vostokgosplan.ru/wpcontent/uploads/2019/04/Predlozheniya-NPRDV.pdf

Fetscherin, M. (2009). Nation Branding: Concepts, Issues, Practice by Keith Dinnie. Dutton: Butterworth-Heinemann. Retrieved from https://www.researchgate.net/publication/200166326_Nation_Branding

Govers, R. (2018). Imaginative communities: Admired cities, regions and countries. Retrieved from https://www.imaginativecommunities.com/sign-up/

Gurov, S. A., \& Korzuhina V. A. (2016). Perception, image, reputation, stereotype, brand of the territory: comparison of categories. Science notes of the Federal State university of V.I. Vernadsky. Geography. Geology, 2(68), 3-22. (in Russian)

Terskiy, M. V., \& Malenova, E. D. (2015). Image of the region: theoretical aspects (Russian and foreign experience). Political Linguistics, 2(52), 199-205. (in Russian) 